INDEKS MASSA TUBUH (IMT) BERHUBUNGAN DENGAN KELUHAN MENOPAUSE

\title{
THE BODY MASS INDEX (BMI) RELATED TO MENOPAUSE SYMPTOMS
}

\author{
Olvinda Eka Zulfi ${ }^{*}$, Sri Ratna Dwiningsih ${ }^{2}$, Ilya Krisnana ${ }^{3}$
}

1. Program Studi Pendidikan Bidan Fakultas Kedokteran Universitas Airlangga, Surabaya, Indonesia

2. Departemen Obstetri dan Ginekologi Fakultas Kedokteran Universitas Airlangga, Surabaya, Indonesia

3. Departemen Keperawatan Maternitas dan Anak Fakultas Keperawatan Universitas Airlangga, Surabaya, Indonesia

Alamat korespondensi:

Jl. Raya Padang - Medan no.298, Panti, Pasaman, Sumatera Barat, Indonesia

Email*: ez.olvinda@gmail.com

\begin{abstract}
Abstrak
Latar Belakang : Menopause merupakan periode alamiah dalam kehidupan seorang wanita yang berhubungan dengan perubahan hormonal dan ditandai dengan berhentinya menstruasi dalam 12 bulan terakhir serta dapat menyebabkan berbagai keluhan yang terkadang mengganggu. Keluhan menopause tersebut dikaitkan dengan beberapa faktor risiko seperti Indeks Massa Tubuh (IMT) dan pengetahuan. Penelitian ini bertujuan untuk mengetahui hubungan IMT dan pengetahuan dengan keluhan menopause pada kelompok pengajian Shafa Padang Petok Nagari Panti Selatan. Metode : Penelitian ini merupakan penelitian analitik observasional dengan pendekatan cross sectional. Teknik pengambilan sampel dilakukan secara total sampling yang terdiri dari 55 responden berdasarkan kriteria inklusi yakni wanita menopause usia 45 - 65 tahun yang belum mengalami demensia dan berkesadaran baik serta bersedia menjadi responden. Data diperoleh dengan melakukan penimbangan berat badan, pengukuran tinggi badan serta pengisian The Menopause Rating Scale untuk mengevaluasi derajat keparahan keluhan terkait menopause oleh responden penelitian. Data kemudian diolah dengan uji Spearman rho untuk melihat hubungan antara IMT dan pengetahuan dengan keluhan menopause. Hasil : Penelitian ini menunjukkan $65,4 \%$ responden dengan IMT tinggi, $72,7 \%$ berpengetahuan kurang dan $60 \%$ mengalami keluhan menopause berat. Hasil uji Spearman rho menunjukkan adanya hubungan antara IMT dengan keluhan menopause ( $\mathrm{p}$ value $=0,000$ ), namun tidak ada hubungan antara pengetahuan dengan keluhan menopause (p value $=0,450)$. Kesimpulan : IMT berhubungan dengan keluhan menopause sehingga wanita menopause harus memantau berat badan mereka sebagai upaya untuk mencegah berbagai keluhan tersebut.
\end{abstract}

Kata Kunci : Menopause, Indeks Massa Tubuh, Keluhan Menopause

\section{Abstract}

Background : Menopause is a natural period in a woman's life related to hormonal changes and is marked by the cessation of menstruation in the last 12 months and can cause a wide range of sometimes bothersome menopause symptoms. That menopause symptoms associated with several risk factors such as Body Mass Index (BMI) and knowledge. The study aims to identify the relationship of BMI and knowledge with menopause symptoms in the Shafa group Padang Petok Nagari Panti Selatan. Method: This research is analitic observational research with cross sectional approach. The sampling technique was carried out by total sampling consisting of 55 respondents with inclusion criteria menopause women aged 45-65 years who have not experienced dementia, have good awareness and willing to be respondents. Data were obtained by weighing, measuring height and filling out The Menopause Rating Scale to evaluate the severity of menopause-related symptoms by respondents. Afterwards the data was 
analyzed by the Spearman rho test to see the association between BMI and knowledge with menopause symptoms. Result : The research shows $65,4 \%$ respondents with high BMI, 72,7\% with lacking of knowledge and $60 \%$ with severe menopause symptoms. The results of the Spearman rho test showed a relationship between BMI and menopause symptoms ( $p$ value $=0.000)$, but there is no relationship between knowledge of menopause and menopause symptoms $(p=0,450)$. Conclusion : BMI related to menopause symptoms. Menopause women must monitor their weight in an effort to prevent these complaints.

Keywords : Menopause, Body Mass Index, Menopause symptoms

\section{PENDAHULUAN}

Umur Harapan Hidup (UHH) wanita di Indonesia mengalami kenaikan dari 70,1 tahun pada 2015 menjadi 73,06 tahun pada 2017 (Kemenkes RI, 2013). Seiring dengan peningkatan UHH ini maka akan terjadi peningkatan penyakit - penyakit tua pada wanita (Sasrawita, 2017). Permasalahan yang secara umum sering dialami di Indonesia adalah permasalahan yang lebih didominasi oleh wanita, salah satunya adalah masalah seputar menopause (Nurningsih, 2012).

Menopause menurut World Health Organization (WHO) merupakan berhentinya siklus menstruasi untuk selama-lamanya pada wanita yang sebelumnya mengalami menstruasi tiap bulan, mengalami amenorea dalam 12 bulan terakhir serta bukan disebabkan oleh keadaan patologis (Hekhmawati, Selvia, 2016). Keluhan keluhan menopause berdampak pada kualitas hidup wanita secara keseluruhan dan dikaitkan dengan beberapa faktor risiko seperti Indeks Massa Tubuh (IMT) dan pengetahuan (Amabebe et al., 2014).

Terdapat hasil yang berbeda terkait efek IMT terhadap keluhan menopause. Beberapa studi menunjukkan bahwa wanita dengan obesitas mengalami keluhan vasomotor yang lebih sedikit jika dibandingkan dengan wanita yang tidak obesitas (Tan, Kartal and Guldal, 2014). Namun, Syalfina (2017) dalam penelitiannya mengungkapkan bahwa wanita dengan berat badan lebih maupun obesitas mengalami lebih banyak keluhan menopause daripada wanita dengan IMT normal.

Seiring dengan peningkatan UHH, penting bagi wanita untuk menyadari berbagai keluhan menopause dan efeknya terhadap status kesehatan secara keseluruhan. Dibutuhkan usaha untuk meningkatkan pengetahuan mereka melalui pendidikan sehingga mampu melakukan pengelolaan secara tepat, mencari pengobatan dan meningkatkan kualitas hidup saat menopause (Satpathy, 2016). 
Hasil studi pendahuluan terhadap 10 orang wanita menopause yang terdaftar sebagai anggota kelompok pengajian Shafa Padang Petok, Nagari Panti Selatan dengan melakukan penghitungan IMT dan pengisian kuesioner didapatkan rerata IMT adalah $25,82 \mathrm{~kg} / \mathrm{m} 2$ yang termasuk dalam kategori obes I. Sembilan dari sepuluh wanita tersebut mempunyai pengetahuan kurang tentang menopause. Rerata mengalami keluhan menopause sedang.

Penelitian ini bertujuan untuk menganalisis hubungan antara IMT dan pengetahuan dengan keluhan menopause pada kelompok pengajian Shafa Padang Petok, Nagari Panti Selatan.

\section{METODE}

Rancangan penelitian yang digunakan adalah analitik observasional dengan pendekatan cross sectional. Populasi pada penelitian ini adalah seluruh wanita menopause yang terdaftar pada kelompok pengajian Shafa Padang Petok, Nagari Panti Selatan. Teknik sampel yang digunakan adalah total sampling. Besar sampel dalam penelitian ini berjumlah 55 responden. Kriteria inklusinya adalah wanita menopause usia 45-65 tahun yang belum mengalami demensia dan mempunyai kesadaran baik serta bersedia menjadi responden. Sedangkan kriteria eksklusinya adalah wanita yang pernah dilakukan histerektomi dan salfingo-ooforektomi bilateral, sedang menggunakan Terapi Sulih Hormon (TSH), sedang menjalani kemoterapi, menderita diabetes melitus, hipertensi, chronic kidney disease, rheumatoid, cerebrovascular accident, kanker, infeksi TB, kista, HIV/AIDS, mempunyai masalah kesehatan jiwa ataupun masalah sosial keluarga dan menderita osteoporosis.

Variabel bebas dalam penelitian ini adalah IMT dan pengetahuan. Variabel terikat adalah keluhan menopause. Indeks Massa Tubuh (IMT) merupakan hasil hitung dari Berat Badan (BB) sekarang dalam kilogram (kg) dibagi dengan Tinggi Badan (TB) dalam meter dikuadratkan (m2). Berat badan diukur dengan menggunakan timbangan digital berkapasitas maks. $200 \mathrm{~kg}$ dan ketelitian 0,1 kg. Tinggi badan diukur dengan menggunakan stature meter berkapasitas ukur maks. $200 \mathrm{~cm}$ dan ketelitian $0,1 \mathrm{~cm}$. IMT berskala ordinal dengan kategori berat badan kurang (IMT < 18,5), normal (IMT 18,5$22,9)$ dan berat badan lebih yang dibagi lagi dalam 3 kategori, yakni berisiko $(23-24,9)$, obes I $(25-29,9)$ dan obes II $(\geq 30)$. 
Pengetahuan merupakan segala sesuatu yang diketahui, dimengerti atau dipahami oleh responden tentang menopause. Pengetahuan berskala ordinal dan diukur menggunakan kuesioner yang diisi oleh responden. Kuesioner pengetahuan dikembangkan sendiri oleh peneliti dan terdiri dari 18 pertanyaan yang merupakan pertanyaan tertutup (closed form questionnaire). Semua pertanyaan di dalam kuesioner ini adalah pertanyaan favorable. Pemberian nilainya adalah nilai 1 untuk jawaban benar dan nilai 0 untuk jawaban salah. Jumlah skor jawaban akan dipresentasikan, kemudian dibagi menjadi tiga kategori yaitu pengetahuan kurang jika jawaban benar $<56 \%$, cukup jika jawaban benar 56- 75\% dan baik jika jawaban benar 76-100\%. Seluruh pertanyaan dalam kuesioner telah melalui uji validitas dan reliabilitas.

Keluhan menopause merupakan gejala - gejala yang tertera di kuesioner penelitian yang diambil dari Menopause Rating Scale (MRS) yang dialami oleh responden saat ini. Kuesioner juga diisi oleh responden. Keluhan menopause berskala ordinal. The Menopause Rating Scale (MRS) dikembangkan oleh The Berlin Center for Epidemiology and Health Research dan telah tervalidasi secara isi. Kuesioner ini terdiri dari 11 item keluhan menopause yang terbagi ke dalam tiga bagian yaitu keluhan psikologi, keluhan somato- vegetatif dan keluhan urogenital. Tiap keluhan dinilai derajat keparahannya dengan empat tolok ukur skala nilai yaitu nilai 0 (tidak ada gejala), nilai 1 (gejala ringan), nilai 2 (gejala menengah), nilai 3 (gejala berat) dan nilai 4 (gejala sangat berat). Skor komposit untuk setiap dimensi (Sub-skalanya) diperoleh setelah menambahkan skor pada setiap item dari masing-masing dimensi. Skor komposit (skor total) diperoleh setelah menjumlahkan semua skor dimensi. Kategori yang digunakan adalah tidak ada/ sedikit keluhan (total skor 0-4), keluhan ringan (total skor 5-8), keluhan sedang (total skor 9-16) dan keluhan berat (total skor $\geq 17$ ).

Pengumpulan data dilakukan pada bulan Desember 2019 dimulai dengan penentuan sampel penelitian. Responden diberi penjelasan mengenai manfaat dan tujuan penelitian, baru sesudahnya diminta menandatangani informed consent sebagai persetujuan menjadi responden. Peneliti melakukan penimbangan BB dan pengukuran TB, kemudian membagikan kuesioner penelitian untuk diisi oleh responden. Data yang sudah dikumpulkan diolah kemudian dianalisis menggunakan uji korelasi Spearman rho dengan bantuan software analisis data. 
Penelitian ini sudah mendapatkan surat layak etik no. 331/EC/KEPK/FKUA/2019 dari Komite Etik Penelitian Kesehatan Fakultas Kedokteran Universitas Airlangga Surabaya pada tanggal 2 Desember 2019.

HASIL DAN PEMBAHASAN

1. Indeks Massa Tubuh (IMT)

Tabel 1 Karakteritik Responden berdasarkan IMT

\begin{tabular}{ccc}
\hline IMT & $\mathbf{n}$ & $\mathbf{\%}$ \\
\hline Kurang & 5 & 9.1 \\
Normal & 14 & 25.5 \\
Berisiko & 14 & 25.5 \\
Obes 1 & 16 & 29.1 \\
Obes 2 & 6 & 10.9 \\
\hline
\end{tabular}

Tabel 1 menunjukkan bahwa Massa Tubuh (IMT) responden dalam kategori berisiko maupun obes lebih besar dibandingkan dengan IMT normal $(65,5 \%)$.

\section{Pengetahuan}

Tabel 2 Karakteritik Responden berdasarkan Pengetahuan

\begin{tabular}{ccc}
\hline Pengetahuan & n & \% \\
\hline Kurang & 41 & 74.5 \\
Cukup & 12 & 21.8 \\
Baik & 2 & 3.6 \\
\hline
\end{tabular}

Tabel 2 menunjukkan bahwa pengetahuan responden tentang menopause sebagian besar berada dalam kategori kurang $(74,5 \%)$.

\section{Keluhan Menopause}

Tabel 3 Karakteristik Responden berdasarkan Keluhan Menopause

\begin{tabular}{ccc}
\hline Keluhan Menopause & n & \% \\
\hline Psikologi & 2 & 3,6 \\
Tidak ada/ Sedikit & 4 & 7,3 \\
Ringan & 24 & 43,6 \\
Sedang & 25 & 45,5 \\
Berat & & 3,6 \\
Somato- Vegetatif & 2 & 20 \\
Tidak ada/ Sedikit & 11 & 34,5 \\
Ringan & 19 & 41,8 \\
Sedang & 23 & 9,1 \\
Berat & & 9
\end{tabular}




\begin{tabular}{ccc} 
Ringan & 0 & 0 \\
Sedang & 10 & 18,2 \\
Berat & 40 & 72,7 \\
\hline
\end{tabular}

Tabel 3 menunjukkan bahwa responden penelitian paling banyak mengalami keluhan psikologis sedang hingga berat (43,6\% dan 45,5\%), keluhan somato- vegetatif berat adalah yang paling banyak dialami responden $(41,8 \%)$ dan sebagian besar responden mengalami keluhan urogenital berat (72,7\%).

Tabel 4 Presentase Hasil Skor Total Keluhan

\begin{tabular}{ccc}
\hline Keluhan Menopause & n & \% \\
\hline Keluhan Psikologi : & 111 & 28 \\
Perasaan Tertekan & 80 & 20 \\
Mudah Marah & 95 & 24 \\
Rasa resah & 115 & 29 \\
Kelelahan fisik dan mental & & \\
Keluhan Somato- vegetatif : & 82 & 24 \\
Badan terasa sangat panas, berkeringat & 80 & 23 \\
Rasa tidak nyaman pada jantung & 76 & 22 \\
Masalah tidur & 107 & 31 \\
Rasa tidak nyaman pada persendian dan otot & & 35 \\
Keluhan Urogenital : & 87 & 35 \\
Masalah seksual & 87 & 30 \\
\hline Masalah pada kandung dan saluran kemih & 75 & \\
Kekeringan pada vagina &
\end{tabular}

Tabel 4 menunjukkan bahwa kelelahan fisik dan mental merupakan yang terbanyak dari keluhan psikologi. Rasa tidak nyaman pada persendian dan otot merupakan yang terbanyak pada keluhan somato- vegetatif. Masalah seksual dan masalah pada kandung dan saluran kemih merupakan yang terbanyak pada keluhan urogenital.

Tabel 5 Karakteritik Responden berdasarkan Keluhan Menopause Total

\begin{tabular}{ccc}
\hline Keluhan Menopause & n & \% \\
\hline Tidak ada/ Sedikit & 0 & 0 \\
Ringan & 4 & 7.3 \\
Sedang & 18 & 32.7 \\
Berat & 33 & 60 \\
\hline
\end{tabular}

Tabel 5 menunjukkan bahwa secara garis besar responden penelitian mengalami keluhan menopause berat (60\%)

4. Analisis Bivariat IMT dengan Keluhan Menopause

Tabel 6 Analisis Bivariat IMT dengan Keluhan Psikologi

\begin{tabular}{llll}
\hline IMT & Keluhan Psikologi & Nilai p & r
\end{tabular}




\begin{tabular}{ccccccc}
\hline & $\begin{array}{c}\text { Tidak ada/ } \\
\text { Sedikit }\end{array}$ & Ringan & Sedang & Berat & & \\
\hline Kurang & 0 & 0 & $2(40 \%)$ & $3(60 \%)$ & 0.013 & 0.333 \\
Normal & $1(7.1 \%)$ & $2(14.3 \%)$ & $10(71.4 \%)$ & $1(7.1 \%)$ & & \\
Berisiko & $1(7.1 \%)$ & $1(7.1 \%)$ & $5(35.7 \%)$ & $7(50 \%)$ & & \\
Obes 1 & 0 & $1(6.3)$ & $6(37.5 \%)$ & $9(56.3 \%)$ & & \\
Obes 2 & 0 & 0 & $1(16.7 \%)$ & $5(83.3 \%)$ & & \\
\hline
\end{tabular}

Tabel 6 menunjukkan bahwa responden dengan IMT tinggi/ berlebih banyak yang mengalami keluhan psikologi berat, sedangkan responden dengan IMT normal hampir seluruhnya mengalami keluhan psikologi sedang (71,4\%). Responden dengan kategori IMT kurang dan obes 2 mengalami keluhan psikologi sedang hingga berat.

Hasil uji korelasi Spearman rho menghasilkan nilai p kurang dari 0,05 yang berarti ada hubungan antara IMT dengan keluhan psikologi. Nilai rho menunjukkan angka positif yang artinya semakin tinggi kategori IMT maka semakin berat keluhan psikologi yang dialami. Tingkat keeratan hubungan antara IMT dengan keluhan psikologi sebesar 0,333 yang artinya hubungan yang terjalin antara keduanya cukup dan memiliki nilai yang bermakna signifikan.

Tabel 7 Analisis Bivariat IMT dengan Keluhan Somato - Vegetatif

\begin{tabular}{|c|c|c|c|c|c|c|}
\hline \multirow[b]{2}{*}{ IMT } & \multicolumn{4}{|c|}{ Keluhan Somato - Vegetatif } & \multirow[b]{2}{*}{ Nilai p } & \multirow[b]{2}{*}{$\mathbf{r}$} \\
\hline & $\begin{array}{c}\text { Tidak ada/ } \\
\text { Sedikit }\end{array}$ & Ringan & Sedang & Berat & & \\
\hline Kurang & 0 & $1(20 \%)$ & $4(80 \%)$ & 0 & 0.000 & 0.727 \\
\hline Normal & $2(14.3 \%)$ & $10(71.4 \%)$ & $2(14.3 \%)$ & 0 & & \\
\hline Berisiko & 0 & 0 & $8(57.1 \%)$ & $6(42.9 \%)$ & & \\
\hline Obes 1 & 0 & 0 & $4(25 \%)$ & $12(75 \%)$ & & \\
\hline Obes 2 & 0 & 0 & $1(16.7 \%)$ & $5(83.3 \%)$ & & \\
\hline
\end{tabular}

Tabel 7 menunjukkan semua responden dengan IMT tinggi/ berlebih mengalami keluhan somato- vegetatif sedang hingga berat. Responden dengan IMT kurang dan normal sama sekali tidak mengalami keluhan somato- vegetatif berat. Responden dengan IMT kategori obes 1 dan 2 paling banyak mengalami keluhan 
somato- vegetatif berat $(75 \%$ dan $83,3 \%)$. Responden dengan IMT kurang hampir seluruhnya mengalami keluhan somato- vegetatif sedang (80\%). Responden dengan IMT normal paling banyak mengalami keluhan somato- vegetatif ringan $(71,4 \%)$.

Hasil uji korelasi Spearman rho menghasilkan nilai p kurang dari 0,05 yang berarti ada hubungan antara IMT dengan keluhan somato- vegetatif. Nilai rho menunjukkan angka positif yang artinya semakin tinggi IMT maka semakin berat keluhan somato- vegetatif yang dialami. Tingkat keeratan hubungan antara IMT dengan keluhan somato- vegetatif sebesar 0,727 yang artinya hubungan yang terjalin antara keduanya kuat dan memiliki nilai yang bermakna signifikan.

Tabel 8 Analisis Bivariat IMT dengan Keluhan Urogenital

\begin{tabular}{|c|c|c|c|c|c|c|}
\hline \multirow[b]{2}{*}{ IMT } & \multicolumn{4}{|c|}{ Keluhan Urogenital } & \multirow[b]{2}{*}{ Nilai $p$} & \multirow[b]{2}{*}{$\mathbf{r}$} \\
\hline & $\begin{array}{c}\text { Tidak ada/ } \\
\text { Sedikit }\end{array}$ & Ringan & Sedang & Berat & & \\
\hline Kurang & 0 & 0 & $1(20 \%)$ & $4(80 \%)$ & 0.009 & 0.348 \\
\hline Normal & $4(28.6 \%)$ & 0 & $5(35.7 \%)$ & $5(35.7 \%)$ & & \\
\hline Berisiko & $1(7.1 \%)$ & 0 & $1(7.1 \%)$ & $12(85.7 \%)$ & & \\
\hline Obes 1 & 0 & 0 & $3(18.8 \%)$ & $13(81.3 \%)$ & & \\
\hline Obes 2 & 0 & 0 & 0 & $6(100 \%)$ & & \\
\hline
\end{tabular}

Tabel 8 menunjukkan tidak ada responden yang mengalami keluhan urogenital ringan. Responden dengan IMT kurang dan kategori obes 1 mengalami keluhan urogenital sedang hingga berat. Seluruh responden dengan IMT kategori obes 2 mengalami keluhan urogenital berat. Responden dengan IMT kurang paling banyak mengalami keluhan urogenital berat $(80 \%)$.

Hasil uji korelasi Spearman rho menghasilkan nilai p kurang dari 0,05 yang berarti ada hubungan antara IMT dengan keluhan urogenital. Nilai rho menunjukkan angka positif yang artinya semakin tinggi IMT maka semakin berat keluhan urogenital yang dialami. Tingkat keeratan hubungan antara IMT dengan keluhan urogenital 
sebesar 0,348 yang artinya hubungan yang terjalin antara keduanya cukup dan memiliki nilai yang bermakna signifikan.

Tabel 9 Analisis Bivariat IMT dengan Keluhan Menopause Total

\begin{tabular}{ccccccc}
\hline \multirow{2}{*}{ IMT } & \multicolumn{3}{c}{ Keluhan Menopause } & \multicolumn{2}{c}{ Nilai p } & r \\
\cline { 2 - 6 } & $\begin{array}{c}\text { Tidak ada/ } \\
\text { Sedikit }\end{array}$ & Ringan & Sedang & Berat & \\
Kurang & 0 & 0 & $2(40 \%)$ & $3(60 \%)$ & 0.000 & 0.598 \\
Normal & 0 & $4(28.6 \%)$ & $10(71.4 \%)$ & 0 & \\
Berisiko & 0 & 0 & $4(28.6 \%)$ & $10(71.4 \%)$ & \\
Obes 1 & 0 & 0 & $2(12.5 \%)$ & $14(87.5 \%)$ & \\
Obes 2 & 0 & 0 & 0 & $6(100 \%)$ & \\
\hline
\end{tabular}

Tabel 9 menunjukkan bahwa responden dengan IMT normal saja yang mengalami keluhan menopause ringan, sedangkan responden dengan IMT kurang dan tinggi/ berlebih mengalami keluhan menopause sedang hingga berat. Seluruh responden dengan IMT kategori obes 2 mengalami keluhan menopause berat, sementara responden dengan IMT normal sama sekali tidak mengalaminya. Responden dengan IMT normal paling banyak mengalami keluhan menopause sedang $(71,4 \%)$.

Hasil uji korelasi Spearman rho menghasilkan nilai p kurang dari 0,05 yang berarti ada hubungan antara IMT dengan keluhan menopause secara keseluruhan. Nilai rho menunjukkan angka positif yang artinya semakin tinggi IMT maka semakin berat keluhan menopause yang dialami. Tingkat keeratan hubungan antara IMT dengan keluhan menopause sebesar 0,333 yang artinya hubungan yang terjalin antara keduanya cukup dan memiliki nilai yang bermakna signifikan.

\section{Analisis Bivariat Pengetahuan dengan Keluhan Menopause}

Tabel 10 Analisis Bivariat Pengetahuan dengan Keluhan Menopause

\begin{tabular}{|c|c|c|c|c|c|c|}
\hline \multirow[b]{2}{*}{ Pengetahuan } & \multicolumn{4}{|c|}{ Keluhan Menopause } & \multirow[b]{2}{*}{ Nilai p } & \multirow[b]{2}{*}{$\mathbf{r}$} \\
\hline & $\begin{array}{c}\text { Tidak ada/ } \\
\text { Sedikit }\end{array}$ & Ringan & Sedang & Berat & & \\
\hline Kurang & 0 & $2(4.9 \%)$ & $13(31.7 \%)$ & $26(63.4 \%)$ & 0.450 & -0.104 \\
\hline Cukup & 0 & $2(16.7 \%)$ & $4(33.3 \%)$ & $6(50 \%)$ & & \\
\hline Baik & 0 & 0 & $1(50 \%)$ & $1(50 \%)$ & & \\
\hline
\end{tabular}


Tabel 10 menunjukkan sebagian besar responden berpengetahuan kurang mengalami keluhan menopause berat $(63,4 \%)$. Responden berpengetahuan cukup sebagian besar juga mengalami keluhan menopause berat (50\%). Responden berpengetahuan baik tidak satupun mengalami keluhan menopause sedikit ataupun ringan.

Hasil uji korelasi Spearman rho menghasilkan nilai $\mathrm{p}$ lebih dari 0,05 yang berarti tidak ada hubungan antara pengetahuan tentang menopause dengan keluhan menopause secara keseluruhan.

\section{Hubungan IMT dengan Keluhan Menopause}

Hasil penelitian menunjukkan 36 responden (65,45\%) mempunyai IMT tinggi/ berlebih. Obesitas pada wanita postmenopause bersifat multifaktorial. Status hormon yang berubah memicu adipositas sentral (Rani and Neelambikai, 2013).

Hasil analisis bivariat tabel 7 menunjukkan bahwa responden dengan IMT tinggi/ berlebih cenderung mengalami keluhan somato - vegetatif sedang hingga berat. Hasil analisis Spearman rho menunjukkan adanya hubungan yang signifikan antara IMT dengan keluhan somato- vegetatif $(p=0,000)$. Tabel 4 menunjukkan bahwa rasa tidak nyaman pada persendian dan otot merupakan keluhan somato- vegetatif yang paling sering dialami (29\%). Hal ini sejalan dengan penelitian yang dilakukan oleh Mohammadzadeh et al. (2017) terhadap 115 wanita postmenopause usia 45- 65 tahun yang menunjukkan bahwa sakit punggung dan nyeri sendi merupakan keluhan menopause dengan prevalensi terbanyak. Nyeri sendi ditimbulkan oleh penipisan protein pembentuk tulang rawan sendi yang terjadi seiring dengan bertambahnya usia. Selain itu penggunaan sendi selama bertahun- tahun juga menyebabkan iritasi dan peradangan tulang rawan. Nyeri sendi lebih sering terjadi pada wanita. Hal ini berhubungan dengan menopause. Saat menopause, hormon estrogen tidak berfungsi lagi, sementara salah satu fungsinya adalah mempertahankan massa tulang (Suharjono et al., 2014). Obesitas memperburuk risiko yang berhubungan dengan keluhan sendi dan otot seperti nyeri lutut, kekakuan sendi dan pembengkakan sendi di tangan pada wanita menopause yang pada gilirannya menyebabkan nyeri sendi dan otot (Zhou et al., 2018). 
Keluhan vasomotor (hot flushes dan night sweats) merupakan salah satu keluhan menopause yang berhubungan dengan obesitas yang paling banyak dipelajari. Hasil penelitian ini menunjukkan bahwa keluhan vasomotor juga merupakan keluhan somatovegetatif yang sering dialami responden (28\%). Keluhan vasomotor menetap dalam 6 bulan hingga 2 tahun, namun dapat bertahan hingga lebih dari 10 tahun. Frekuensi dan keparahannya berbeda pada setiap wanita. Keluhan vasomotor berefek terhadap kualitas hidup dengan menyebabkan insomnia, depresi, kecemasan dan kelelahan (Techatraisak \& Jiwornlerk, 2019). Patofisiologinya masih belum dipahami dengan baik. Dua mekanisme yang saling bertentangan telah diusulkan dalam menjelaskan dugaan hubungan antara obesitas dan keluhan vasomotor. Hipotesis pertama menyatakan bahwa wanita obes lebih rentan terhadap keluhan vasomotor karena adipositas atau lemak tubuh bertindak sebagai insulator. Obesitas mungkin menghambat disipasi panas yang dihasilkan dari peningkatan temperatur tubuh internal yang timbul dari mekanisme termoregulasi normal. Mekanisme lainnya mengemukakan bahwa wanita obes mungkin memiliki sirkulasi level estrogen yang lebih tinggi karena lemak tubuh adalah sumber estrogen dan konversi perifer androgen menjadi estrogen terjadi di jaringan adiposa. Tingkat estrogen yang tinggi pada obesitas dapat mengurangi gejala vasomotor. Mekanisme ini sering disebut "thin hypothesis" (Koo et al., 2017).

Penelitian yang dilakukan oleh Amabebe et al., (2014) terhadap wanita pre, peri dan postmenopause selama melakukan olah raga sedang (moderate exercise) menyatakan adanya korelasi yang signifikan dan positif antara IMT dan SR (sweat rate) $(\mathrm{p}<0,05)$; dan SV (sweat volume) $(\mathrm{p}<0,01)$. Peningkatan keringat saat menopause berkaitan dengan peningkatan IMT terutama selama periode transisi perimenopause. Zona thermoneutral wanita obes cenderung menyempit sehingga menyebabkan mereka lebih banyak berkeringat. Disfungsi termoregulasi pada wanita obes juga bisa terjadi karena perubahan kadar leptin. Leptin menurunkan pembentukan estrogen dari prekursor androgen yang bersirkulasi dan menyebabkan termodisregulasi dengan meningkatkan suhu tubuh inti. Kadar serum leptin meningkat pada wanita paruh baya yang obes.

Hasil analisis bivariat tabel 6 menunjukkan bahwa responden dengan IMT tinggi/ berlebih banyak yang mengalami keluhan psikologi berat yaitu sebanyak 21 orang (84\%). Hasil analisis Spearman rho menunjukkan adanya hubungan yang signifikan antara IMT dengan keluhan psikologi $(p=0,013)$. Tabel 4 menunjukkan bahwa 
kelelahan fisik dan mental merupakan keluhan psikologi yang paling sering dialami (31\%). Hal ini sejalan dengan penelitian yang dilakukan oleh Joseph et al. (2014) terhadap wanita menopause usia 40- 65 tahun di Canara Selatan, India yang mendapatkan hasil bahwa keluhan menopause yang paling sering dilaporkan adalah kelelahan fisik dan mental $(85,4 \%)$. Olahraga dan obesitas memainkan peran penting pada persepsi individu tentang kesehatan dan kualitas hidup yang baik. Wanita menopause yang tidak berolahraga atau berolahraga secara tidak teratur lebih mungkin mengalami kelelahan fisik dan mental. (Jaber et al., 2019).

Hasil analisis bivariat tabel 8 menunjukkan bahwa responden dengan IMT tinggi/ berlebih banyak yang mengalami keluhan urogenital berat yaitu sebanyak 31 orang (75,60\%). Hasil analisis Spearman rho menunjukkan adanya hubungan yang signifikan antara IMT dengan keluhan urogenital $(p=0,009)$. Tabel 4 menunjukkan bahwa masalah pada kandung dan saluran kemih serta masalah seksual merupakan keluhan urogenital yang paling sering dialami (masing- masing 35\%). Keluhan urogenital berhubungan langsung dengan berkurangnya kadar estrogen yang bersirkulasi setelah menopause. Defisiensi estrogen setelah menopause dapat menyebabkan gejala saluran kemih bagian bawah, seperti disuria, urgensi, frekuensi, nokturia, inkontinensia urin (UI), dan ISK berulang (Kim et al., 2015). Masalah uroginekologi seperti lemahnya otot dasar panggul, inkontinensia urin, dan prolaps body panggul adalah masalah kesehatan masyarakat yang serius yang mungkin memiliki efek negatif pada fungsi seksual dan kualitas hidup (Dąbrowska-Galas et al., 2019). Geng et al. (2018) dalam penelitiannya menegaskan bahwa risiko GSM (Genitourinary Syndrome of Menopause) lebih tinggi pada wanita postmenopause dan IMT $\geq 30 \mathrm{~kg} / \mathrm{m}^{2}$.

Tabel 9 antara IMT dengan keluhan menopause secara keseluruhan hasil analisis Spearman rho menunjukkan adanya hubungan yang signifikan antara keduanya $(\mathrm{p}=$ 0,000). Hasil ini berbeda dengan teori yang telah dijelaskan sebelumnya. Hal ini mungkin terjadi karena adanya faktor- faktor lain selain IMT yang tidak diteliti dalam penelitian ini seperti sikap, dukungan keluarga, merokok maupun masalah kesehatan lain yang secara langsung maupun tidak langsung ikut memengaruhi keluhan menopause yang dialami responden. Selain itu, tingkat keparahan keluhan menopause juga tergantung pada faktor sosial, budaya dan biologis yang mungkin berbeda- beda di setiap individu, budaya, waktu, dan tempat (Shre, et al., 2016). 
Obesitas dan overweight mengurangi kualitas hidup saat menopause. Hal ini disebabkan oleh citra diri yang negatif serta penurunan aktifitas fisik pada wanita obes (Namazi et al., 2019). Obesitas adalah masalah yang berkembang pesat secara global. Wanita postmenopause dengan IMT tinggi memiliki efek negatif signifikan terhadap tekanan darah, glukosa darah dan profil lipid dengan trigliserida yang tinggi dan kolestrol HDL yang rendah, peningkatan risiko penyakit kardiovaskuler, malignansi dan mortalitas. Modifikasi gaya hidup dengan berolahraga dan pembatasan kalori diet merupakan manajemen IMT andalan bersama farmakoterapi dan operasi bariatrik dapat pula menjadi tambahan yang bermanfaat (Atapattu, 2015).

\section{Hubungan Pengetahuan dengan Keluhan Menopause}

Tabel 3 menunjukkan bahwa sebagian besar responden berpengetahuan kurang (74,5\%). Hal ini sesuai dengan hasil penelitian Satpathy (2016) yang melibatkan 100 orang responden usia 40- 60 tahun dan menunjukkan bahwa pengetahuan yang benar terkait keluhan menopause, komplikasi dan metode pencegahannya masih kurang dari $50 \%$.

Tabel 10 antara pengetahuan dengan keluhan menopause menunjukkan bahwa sebagian besar responden yang berpengetahuan kurang mengalami keluhan menopause berat $(63,4 \%)$. Namun hasil analisis Spearman rho menunjukkan tidak adanya hubungan yang signifikan antara pengetahuan tentang menopause dengan keluhan menopause $(p=0.450)$. Hal ini mungkin terjadi karena kuesioner penelitian yang digunakan hanya menanyakan tentang pengetahuan responden secara umum terkait menopause dan tidak spesifik menanyakan tentang keluhan menopause yang dialami maupun cara mengatasinya. Selain itu, terbatasnya sampel penelitian mungkin juga bisa menjadi penyebab tidak signifikannya hubungan tersebut secara statistik. Penelitian ini sejalan dengan penelitian Kwak, Park dan Kang (2014) dan Namazi, Sadeghi dan Moghadam (2019) yang menyatakan tidak terdapat hubungan yang signifikan antara pengetahuan tentang menopause dengan keluhan menopause.

Pendidikan responden paling banyak adalah tamat SD (87,3\%). Pendidikan akan memengaruhi pengetahuan seseorang. Makin tinggi tingkat pendidikan seseorang maka makin mudah baginya untuk menerima informasi (Tarigan et al., 2019). Wanita dengan pendidikan lebih rendah cenderung mengalami keluhan menopause yang lebih berat dan wanita dengan pendidikan lebih tinggi lebih mengetahui keluhan menopause dan 
mempunyai strategi khusus untuk menghadapinya serta lebih mungkin untuk mencari pengobatan untuk keluhan menopause yang mereka alami (Namazi, Sadeghi dan Moghadam, 2019).

Kendala dalam penelitian ini adalah kurangnya pemahaman responden terhadap pertanyaan seputar menopause yang diajukan padanya sehingga harus dibacakan dan dijelaskan maksud dari setiap pertanyaan tersebut. Hal ini menyebabkan pengambilan data tidak dapat dilakukan dalam satu waktu karena harus dilakukan door to door sehingga membutuhkan waktu yang relatif lama dalam pelaksanaannya.

\section{KESIMPULAN DAN SARAN}

Hasil analisis dalam penelitian ini menghasilkan kesimpulan bahwa IMT berhubungan dengan keluhan menopause, sedangkan pengetahuan tidak berhubungan dengan keluhan menopause. Responden dengan IMT tinggi masih banyak. Responden diharapkan dapat menjaga dan mempertahankan berat badan ideal dengan melakukan olah raga teratur dan menjaga pola makan. Untuk meminimalkan nyeri otot dan sendi, responden disarankan tidak memaksakan diri melakukan aktivitas fisik berbahaya. Responden yang sering mengalami kelelahan fisik dan mental diharapkan mempunyai waktu tidur yang cukup di malam hari, berekreasi atau melakukan kegiatan lain yang menyenangkan dan dapat menenangkan pikiran. Responden dengan gangguan urogenital diharapkan dapat segera memeriksakan diri ke Puskesmas guna mendapatkan pengobatan terbaik.

\section{DAFTAR PUSTAKA}

Amabebe, E., Osayande, S. I., Ozoene, J. O., \& Ugwu, A. C. (2014). Relationship between Menopausal Sweating and Body Mass Index. Open Journal of Endocrine and Metabolic Diseases, 04(06), 137-146. https://doi.org/10.4236/ojemd.2014.46014

Atapattu, P. M. (2015). Obesity at Menopause: An Expanding Problem. Journal of Patient Care, 01(01), 1-7. https://doi.org/10.4172/2573-4598.1000103

Dąbrowska-Galas, M., Dąbrowska, J., \& Michalski, B. (2019). Sexual Dysfunction in Menopausal Women. Sexual Medicine, 7(4), 472-479. https://doi.org/10.1016/j.esxm.2019.06.010

Geng, L., Zheng, Y., Zhou, Y., Li, C., \& Tao, M. (2018). The prevalence and determinants of genitourinary syndrome of menopause in Chinese mid-life women: a single-center study. Climacteric, 21(5), 478-482. https://doi.org/10.1080/13697137.2018.1458832 
Joseph, N., Nagaraj, K., Saralaya, V., Nelliyanil, M., \& Jagadish Rao, P. (2014). Assessment of menopausal symptoms among women attending various outreach clinics in South Canara District of India. Journal of Mid-Life Health, 5(2), 84. https://doi.org/10.4103/0976-7800.133996

Kim, H.-K., Kang, S.-Y., Chung, Y.-J., Kim, J.-H., \& Kim, M.-R. (2015). The Recent Review of the Genitourinary Syndrome of Menopause. Journal of Menopausal Medicine, 21(2), 65. https://doi.org/10.6118/jmm.2015.21.2.65

Koo, S., Ahn, Y., Lim, J. Y., Cho, J., \& Park, H. Y. (2017). Obesity associates with vasomotor symptoms in postmenopause but with physical symptoms in perimenopause: a cross-sectional study. BMC Women's Health, 17(1), 126. https://doi.org/10.1186/s12905-017-0487-7

Kwak, E. K., Park, H. S., \& Kang, N. M. (2014). Menopause Knowledge, Attitude, Symptom and Management among Midlife Employed Women. Journal of Menopausal Medicine, 20(3), 118. https://doi.org/10.6118/jmm.2014.20.3.118

Mohammadzadeh, S., Hedayati, Z., Ahmadi, N., \& Bayyani, F. (2017). Caspian Journal of Reproductive Medicine Prevalence and severity of menopausal symptoms among menopausal. 3(2), 21-26.

Namazi, M., Sadeghi, R., \& Moghadam, Z. behboodi. (2019). Social Determinants of Health in Menopause: An Integrative Review. International Journal of Women's Health, 11, 637-647. https://doi.org/https://doi.org/10.2147/IJWH.S228594

Nurningsih. (2012). Tentang Menopause Dengan Keluhan Cijantung Kecamatan Pasar Rebo Jakarta Timur Tahun 2012.

Sasrawita, S. (2017). Hubungan Pengetahuan, Sikap Tentang Menopause Dengan Kesiapan Menghadapi Menopause Di Puskesmas Pekanbaru. Jurnal Endurance, 2(2), 117. https://doi.org/10.22216/jen.v2i2.1853

Satpathy, M. (2016). A Study on the Knowledge and Awareness about Menopause among Middle Aged Women from Western Odisha. International Journal of Science and Research (IJSR), 5(7), 1759-1761.

Suharjono, S., Haryanto, J., \& Indarwati, R. (2014). Pengaruh Senam Lansia terhadap Perubahan Nyeri Persendian pada Lansia di Kelurahan Komplek Kenjeran, Kecamatan Bulak, Surabaya. Indonesian Journal of Community Health Nursing, 2(2), 106-110. https://doi.org/10.7202/1016404ar

Tarigan, I., Sinuhaji, L. N. br, \& Sembiring, M. (2019). MENOPAUSE DI PUSKESMAS KABANJAHE Imarina Tarigan , 2 ) Lidya N Br Sinuhaji , 3 ) Mediana Sembiring Program Studi Kebidanan STIKes Mitra Husada Medan Keywords: Menopause, Life Quality, Growing Old Women. Jurnal Mutiara Ners, 2, 158-167.

Techatraisak, K., \& Jiwornlerk, N. (2019). Association between body mass index and moderate-to-severe vasomotor symptoms in Thai postmenopausal women. Siriraj Medical Journal, 71(5), 370-376. https://doi.org/10.33192/Smj.2019.56

Zhou, Y., Zheng, Y., Li, C., Hu, J., Zhou, Y., Geng, L., \& Tao, M. (2018). Association of body composition with menopausal symptoms in (peri-)menopausal women. Climacteric, 21(2), 179-183. https://doi.org/10.1080/13697137.2018.1428295 